\title{
Global History: Opportunities, Dangers, Recent Trends*
}

\author{
Jürgen Kocka \\ Humboldt-Universität zu Berlin, Germany \\ e-mail: juergen.kocka@asa.hu-berlin.de
}

Received: 11 August 2011; Accepted: 18 November 2011; Published online: 23 February 2012

\begin{abstract}
In contrast to national historical approaches, global history responds to the cultural and intellectual needs of communities, societies and cultures which are increasingly interconnected. Global history is an appropriate way of looking to "our past", in an era of accelerated globalization, helping to "deprovincialize" the discipline. For historians of Europe, global history approaches offer a useful ground for embedding, relativizing and enriching their views and perspectives, even when they continue to work as historians of Europe and do not contemplate to become global historians.

As many examples show, global history is emerging as a field in which new forms of cooperation between history and the neighbouring disciplines, particularly the social sciences, can be practiced in new ways. Global history revives the interest in comprehensive structures and large-scale processes; it enhances the analytical power of history as a discipline. It also raises several problems which are not yet resolved. Very different types of discourses and studies are usually lumped together under the heading of "global history", four of them are here considered.
\end{abstract}

KEYWORDS: global history; historiography; historical research; new historical trends.

*This paper was presented to a Symposium organized by the International Committee of Historical Sciences and the Association of Japanese Historians at the University of Tokyo, 12 September 2009.

Citation / Cómo citar este artículo: Kocka, J. (2012) "Global History: Opportunities, Dangers, Recent Trends". Culture \& History Digital Journal, 1(1): e002. doi: http://dx.doi.org/10.3989/chdj.2012.002

RESUMEN: Historia global: oportunidades, peligros, tendencias recientes.- En contraste con los enfoques de la historia nacional, la historia global responde a las necesidades culturales e intelectuales de comunidades, sociedades y culturas que están interconectadas de forma creciente. La historia global es una forma apropiada de mirar "nuestro pasado" en una era de acelerada globalización, ayudando a "des-provincializar" la disciplina. Para los historiadores de Europa, los enfoques de la historia global ofrecen una útil base para alojar, relativizar y enriquecer sus puntos de vista y perspectivas, incluso si continúan trabajando como historiadores de Europa y no quieren convertirse en historiadores globales propiamente dichos.

Como muchos ejemplos muestran, la historia global está emergiendo como un campo en el que nuevas formas de cooperación entre la historia y las disciplinas vecinas, particularmente las ciencias sociales, pueden ser probadas y practicadas en nuevos modos. La historia global revive el interés en estructuras comprensivas y procesos a gran escala, y mejora el poder analítico de la historia como disciplina. Generalmente, bajo el título de "historia global" se incluyen estudios y tipos de discurso muy diferentes; aquí se consideran cuatro de ellos.

PALABRAS CLAVE: historia global; historiografía; investigación histórica; nuevas tendencias historiográficas.

Copyright: (C) 2012 CSIC. This is an open-access article distributed under the terms of the Creative Commons Attribution-Non Commercial (by-nc) Spain 3.0 License. 


\section{ONE}

In the way they talk about history, historians are influenced by their specific experience, regional and cultural background, professional profile and expertise. Although my work has transnational dimensions with much interest for large-scale comparison, I am basically a historian of Europe with emphasis on Germany and the modern period. Please keep this in mind while you consider my comments on global history.

\section{TWO}

History as a scholarly discipline was never restricted to the national level. Local and regional history have always been strong. Historians have traditionally studied ideas, religion, commerce and many other areas of transnational or transregional scope. There are important traditions of world history in several parts of the world, dating back to Herodot and Polybios, Sima Quian or Ibn Khaldun. Or think of Otto Hintze, Fernand Braudel and Eric Hobsbawm, famous historians of the 20th century who produced remarkable works with a transnational approach.

Still, ever since the early 19th century, when history began to emerge (in Europe) as a specialized, professionalized discipline, national historical approaches moved to the foreground. The rise of history as a professional discipline in the universities, schools and public space was part of cultural nation-building. The rise of history as a mass discipline was supported by the emerging or self-empowering nation states, while historians interpreted the relationship between the past, the present and the future in ways conducive to the formation and affirmation of national identities. The methodological principles of the profession, which became standardized and powerful in the same period of time, predisposed historians for this national function: Historians learned to base their studies on primary sources, especially in archives organized by the states; they privileged texts over other sources, which made the knowledge of language indispensable and limited the reach of historical research; they were obliged to take contexts serious and study them closely; they were trained to aim at time-specific and space-specific descriptions, explanations and interpretations, and not for the type of broad generalizations favoured by the natural scientists and some in the slowly rising social sciences.

In this formative period - the 19th century for the West - the public functions and the methodological characteristics of history as a discipline re-enforced each other and prepared the way for the relative dominance of national-historical approaches.
This did not necessarily mean that historians were nationalists (though many of them were). Nor did it mean that all historians wrote comprehensive histories of the countries in which they lived (most historians did not, but concentrated on more specific topics). But it meant that the intellectual maps which historians used for placing and framing their topics were increasingly structured by differences between national cultures and borders between nation states. It also meant that most historians focused on and regarded themselves as competent in specific national histories (and not others), frequently (but not necessarily) the national historical contexts of their own countries. This was particularly true for those historians who played roles as public intellectuals since the textbooks which they could try to influence, and the debates in which they engaged, were primarily informed by national-cultural contexts defined by language, shared communication, common beliefs and national institutions.

Of course, the world has changed much since the 19th century. Nationalism has led to catastrophe, historians have become less nationalistic, history was thoroughly diversified; comparative, micro, regional, ethnic, analytical approaches have gained ground. The old alliance between history as a discipline and the nation state has been loosened. On the other hand, much has survived of the classical historical paradigm, both in the methods and the public functions of historians, spreading throughout the world, changing on the way and becoming highly varied, but still with impressive continuity. As a consequence - due to good and bad reasons -, national historical views and approaches continue to weigh heavily in our profession, and in some parts of the world they are even dominant.

\section{THREE}

This is, I believe, the background that has made global history so attractive since the late 1980s and early 1990s, when the concept "global history" started to be used, when global or world historical journals and associations were founded, and when a lively programmatic debate was brought on the way slowly followed by substantial research and empirical literature with a global-historical reach.

Very different types of discourses and studies are usually lumped together under the heading of "global history". Let me distinguish four of them, following Conrad et al. (2007).

First, there is a new interest in the history of the world economy, moving beyond the old "world system approach" as practiced by Immanuel Wallerstein in the 1970s and 80s. The debate about the "Great Divergence" is perhaps the best known example. It deals with the question of whether and 
why the economic developments of China's Yangtse Delta region and North Western Europe were roughly similar over the centuries (with perhaps a small Chinese lead), while the Industrial Revolution dramatically changed the relation between both regions since the 18th century, with England and other parts of Europe taking off and China stagnating. Pomeranz (2000) tried to give an answer. According to him, the emerging gap was owed less to internal developments of the English economy, but more to external conditions. "Forces outside the market and conjunctures beyond Europe deserve a central place in explaining why Western Europe's otherwise largely unexceptional core achieved unique breakthroughs and wound up as the privileged centre of the 19th century's new world economy."

Second, historical analyses of civilizations have experienced a remarkable come-back, more than a hundred years after Buckle, Danilevsky and Toynbee. Here historically minded social scientists play a role, but so do historians. I am thinking of Samuel Huntington's "Clash of Civilizations", but even more so of Shmuel Eisenstadt's theory of "multiple modernities" which can be seen as an alternative both to Huntington and to classical modernization theory in that it explicitly emphasizes the equal rights of different historical developments in different regions of the world, rejecting the idea of Europe or the West as being a superior model to which all other experiences are compared. There is much controversial debate about the "multiple modernities" approach, but historians have picked up its concepts and its spirit, e.g. Tu Wei-ming in his studies about Confucianism and a particular Chinese way into modernity. This discussion about modernities instead of modernization invites broad comparisons, but even more so the search for interaction between different civilizations and different religions. This way the units of analysis - civilizations - are handled as units with perforated, fluid borders and as parts of a larger whole (which, in itself, is not really theorized). The search for interaction and exchanges has become central for this and many other types of global history.

Third, I want to mention the history of globalization, not in the sense of increasing convergence, but of increasing interdependence, intensified mutual perceptions, interactions and exchanges between different parts of the world, on different levels of analysis: with respect to economic integration, empires and nations and their relations to one another (including war and violence), cultural change between convergence and differentiation, interrelated perceptions of time and space, transport and communication, patterns of migration. It is useful to distinguish between globalization as a process and globalization as a perspective.
Globalization as a process has a long history, according to some with roots in antiquity, according to others since the early 16th century when colonialism began and Europe began to dominate commerce across continents. Historians like Anthony Hopkins and C. A. Baily have distinguished different phases of accelerated globalization, among them the late 18th century, the decades before World War I and the most recent phase of accelerated globalization from the 1980s up to the present time. Clearly, these protracted, non-linear processes, unequally distributed over space and between historical dimensions, subject to interruptions and even reversals, offer much to be studied, not only by modern historians but also by historians of older periods. Globalization as a perspective is younger, and while it is difficult to exactly determine when it started, it can be said that it did not become influential and widespread among historians before the late 1980s or early 1990s.

Fourthly, postcolonial approaches must be mentioned, as they were also particularly influential since the 1980s. Here the impact of historians and intellectuals from non-Western parts of the world from India, from Egypt, later from East Asia, too has been important. The emphasis was and still is on the asymmetric relations between the colonizers from the West and the colonized in the nonWestern world, frequently placing particular emphasis on cultural dimensions. But attention was not only (and not primarily) directed to the impact that the metropolis had on the dependent periphery. Rather, attention was redirected to the influence that the periphery had on the centre, India on Britain, parts of the "Orient" on parts of the West. Said's "Orientalism" had a deep impact, so had the "Subaltern" school of Indian historians - in both cases we see intellectuals with origins outside the West, but deeply immersed in the critical discourses within Western centres of academic life.

The impact of postcolonial thought and politics has strengthened and cultivated the antiEurocentric thrust so strong in many writings of global history in the last two decades. Pointing out that Europe and the West were not just acting subjects of history, but receiving and dependent objects of constellations and processes involving the non-Western world, deconstructing European and Western feelings of superiority so strong in earlier decades and centuries, demonstrating that European and Western leads and advantages were not (or not only) internally created, but partly externally produced, namely by asymmetric interactions and relations of inequality and power, "provincializing" Europe and the West (Chakrabarty, 2000) or "Re-Orienting" global history (to borrow from Frank, 1998) - this became a widespread inclination and passion that continues to motivate many adherents of global 
history, particularly in Western countries. But not all global historians engage in "Europe-bashing" and the deconstruction of "the West".

\section{FOUR}

The meaning of "global history" varies to a certain extent. In contrast to most forms of "universal history" (much stronger in previous decades and centuries), global history today is not teleological. By contrast with some types of "world history" one should emphasize that "global history" is not only defined by its global reach, but also by its emphasis of interactions, exchanges and interrelations across the boundaries between national states, regions, continents and cultures. Maybe one should add a third criterion in order to grasp the core of present-day global history. It is its notion of difference. What most global historians try to avoid is to understand observable differences between nations, cultures, regions and civilizations in a temporal way, i.e. in terms of "not yet" and "already", as indicators of advancement and backwardness on a way towards global convergence according to models offered by the West. Instead of expecting a universal trend towards more convergence and homogenization, global historians are not surprised to detect that increasing interaction may produce new differences, e.g. in the cultural field. This way they distinguish themselves from earlier modernization theory both inside and outside the Marxist tradition.

But the borderlines are not absolutely clear. Take "The Rise of the West" (McNeill, 1963), that is frequently seen as one of the pioneering works in global history. Or take "The Wealth and Poverty of Nations" (Landes, 1998) as one of the most widely read books on global economic and social history. Both authors write from a perspective that acknowledges European or Western "comparative advantages" and role models, vividly rejected by others. The field of global history is highly diversified in itself, and it has grown tremendously over the last two decades.

Why? Global history started to take off in the U.S. in the late 1980s, fuelled by demands from the side of high school and college teaching curricula. Given the increasing importance of immigration from different regions of the world and the impact of identity politics of ethnic minorities, the traditional surveys covering "Western Civilization" were criticized and sometimes replaced by World History or Global History courses. The end of the Cold War stimulated thinking in terms of worldwide interactions and interrelations instead of EastWest comparisons. Most important I think has been globalization as a process which accelerated and intensified in the $1980 \mathrm{~s} / 90$ s with the digital revolution, the end of the East-West divide, the fast expansion of capitalism and changes in traffic patterns and communication. These trends were, on the intellectual level, paralleled, reflected and articulated by the spread of network thinking and theories, emphasizing interaction, reciprocity and feedback instead of causes, consequences and unilinearity. These concepts, imaginations and rhetoric squared well with boundary crossing, entanglements, open structures and ambivalence so dear to modern global history thought.

\section{FIVE}

Not everybody is a convinced believer in the virtues of global history. Objections have been raised. Indeed, one should see the problems inherent to such approaches. Three of them will be mentioned:

(1) Historians are used to investigate very closely the materials and problems they study. They take the specific contexts of their objects very seriously. They prefer to read source materials in the languages in which they were produced. They are trained to arrive at statements - descriptions, explanations, interpretations - that are period and site-specific. These are the standards of the profession. Relative to them it can be risky to write about phenomena of global scope. There is the danger of superficiality. What must be avoided is global history as "history light" which would lend itself easily to ideologization. But as successful examples and many experiences prove, this danger can be avoided: by modesty in the formulation of the aims, by a high degree of self-critical reflexivity on the side of the practitioners, and by knowledge, erudition, skill and a sense of proportion which are signs of maturity in a scholar. Global history belongs to the most difficult tasks historians can shoulder. It is not for beginners.

(2) It is easy to overrate interactions and relations as explanatory factors. In order to explain basic economic, cultural, social and political changes, it is also necessary to study problems and solutions, tensions, conflicts and developments inside economies, societies, cultures and political entities, the importance of their relations to other economies, societies, cultures and political units notwithstanding. This is the most basic reason why global historians should not neglect comparisons, this means, they should not neglect asking for similarities and differences and using them for explanation and interpretation. Whenever global historians limit 
their work on the reconstruction of interactions, interrelations and entanglements only, they run the danger of over-simplification, or they shy away from the task of explanation.

(3) Most works in global history are done in the U.S., in some countries of Europe (especially Great Britain), and now increasingly also in Eastern Asia. One should not forget that even the most encompassing study of global phenomena is based on viewpoints and concepts influenced by the regional, cultural and intellectual context of which the author is part. This is why it is indispensable to have global historical interpretations from different regional and cultural contexts that have to take notice of and compete with one another. Internal pluralism is a necessary condition of success within global history. Otherwise new forms of asymmetric relations and imbalances are likely to emerge, within the interpretation of global history.

But, when assessing problems of global history today, it should be remembered that global history is a minority phenomenon. It is safe to predict that it will remain a minority phenomenon for a long time to come. There is no danger at all that global history will push aside or crowd out national history and other forms of historical study that fulfil cultural, social and political needs not served by global history, and that are frequently less demanding and more popular than global history. Global history is a highly demanding and basically critical supplement to the main body of historical research and writing, which nearly everywhere continues to be strongly structured around national historical paradigms and other non-global views. It can help to modify and refine national historical approaches without making them obsolete.

Given this situation, not the problems but the opportunities of global history weigh heavily. They should be emphasized in conclusion.

In contrast to national historical approaches, global history responds to the cultural and intellectual needs of communities, societies and cultures that are increasingly interconnected. Global history is an appropriate way of looking to "our past" in an era of accelerated globalization.

Some kind of ethnocentrism, nationalism and cultural self-referentiality colours the work of many historians in many parts of the world. Global history can be useful as an antidote. It can question and relativize such intellectual and cultural selflimitations that are so powerful in our discipline. Global history can help to "de-provincialize" the discipline. There is a basic affinity between the potential of global history and the aims of ICHS - the International Committee of Historical Sciences - when trying to organize the world community of historians in the 20th and 21st centuries. For historians of Europe - particularly when they come from European countries - global history approaches offer a useful ground for embedding, relativizing and enriching their views and perspectives even when they continue to work as historians of Europe and do not want to become global historians.

As many examples show, global history is emerging as a field where new forms of cooperation between history and the neighbouring disciplines, particularly the social sciences, can be tried out and practiced in new ways. Global history revives the interest in comprehensive structures and large-scale processes that historians with micro-historical or cultural-historical preferences have frequently neglected in recent decades. Global history makes it necessary to take large and comprehensive contexts (Zusammenhänge) seriously and offers approaches to study them. This way it enhances the analytical power of history as a discipline.

I want to close with a sense of modesty. In some cases global historians write encompassing, integrated and balanced histories of the world during a specific period. Take the books on the 19th century by C. A. Bayly (2004) and J. Osterhammel (2009) as outstanding examples. More frequent is the global historical discussion of a specific problem like the "Great Divergence" between China and Western Europe or the history of work (e. g. by Marcel van der Linden, 2008). Studies of this kind combine topical focus with global scope. Even more frequent are studies on specific topics in a specific country or region, studies that embed their topic in a global historical context by seeing it as part of global developments. Frequently they succeed in developing new perspectives on topics and problems that would look different if they were situated exclusively in a national historical framework. Sebastian Conrad's study on nation, nationalism and work in the German Empire (Conrad, 2006) makes use of such an approach.

In other words, global history appears in very different forms. Sometimes it is the empirical core, the major content of a full-fledged and encompassing presentation. Sometimes it is the medium in which certain historical problems are analyzed. Sometimes it is just a perspective that informs, e.g. a study of primarily national historical content. One does not have to become a global historian in order to profit from global history.

\section{REFERENCES}

Bayly, C.A. (2004) The Birth of the Modern World 1780-1914. Global Connections and Comparisons. Blackwell, Oxford.

Conrad, Sebastian (2006) Globalisierung und Nation im Deutschen Kaiserreich. Verlag C. H. Beck, München. 
Conrad, Sebastian, Andreas Eckert and Ulrike Freitag (Hg.) (2007) Globalgeschichte Theorien, Ansätze, Themen. Campus Verlag, Frankfurt/New York.

Chakrabarty, Dipesh (2000) Provincializing Europe: Postcolonial Thought and Historical Difference. Princeton University Press.

Frank, Andre Gunder (1998) ReOrient: Global Economy in the Asian Age. University of California Press, Berkeley.

Landes, David S. (1998) The Wealth and Poverty of Nations: Why Some Are So Rich and Some So Poor. W.W. Norton \& Company, New York.
Linden, Marcel van der (2008) Workers of the World: Essays Towards a Global Labor History (Studies in Global Social History). Brill, Leiden/Boston.

McNeill, William (1963) The Rise of the West: A History of the Human Community. University of Chicago Press.

Osterhammel, Jürgen (2009) Die Verwandlung der Welt. Eine Geschichte des 19. Jahrhunderts. Verlag C. H. Beck, München.

Pomeranz, Kenneth (2000) The Great Divergence: Europe, China, and the Making of the Modern World Economy. Princeton University Press. 